\title{
THE EXTERNAL ENVIRONMENT AND ITS INFLUENCE ON THE DEVELOPMENT OF MILITARY AND CIVILIAN HIGHER EDUCATION INSTITUTIONS
}

\author{
Elisabeta-Emilia HALMAGHI \\ "Nicolae Bălcescu" Land Forces Academy, Sibiu, Romania \\ emmahalmaghi@gmail.com
}

\begin{abstract}
Higher education institutions, as organizations that "provide education", are those that generate and transfer knowledge to society through teaching and research activities. Viewed as open systems, higher education institutions influence and, in turn, are influenced by their external environment. In the case of military institutions of higher education, the particularities of the military environment determine the appearance of specific characteristics of the external environment.
\end{abstract}

KEYWORDS: influence of the external environment, military and civilian higher education institutions, macro-environment, micro-environment

\section{Introduction}

The concept of "organization environment" is a complex concept that considers how its exogenous and endogenous components help to understand how organizations, as open systems, function. Organizations are considered the way in which certain needs of society, as an environment in which organizations are established and develop, are met. In the literature, the environment of an organization is encountered under the following phrases: "external environment", "environment", "external environment".

\section{Methodology}

The paper addresses the issue of the external environment of military and civilian higher education institutions. Based on the literature and their own observations, the definitions of the external environment of the two types of higher education institutions, the characteristics of the microenvironment and the categories of factors influencing the macroenvironment of military and civilian higher education institutions (hereinafter MCHEI) are presented and analyzed.

\section{Military and Civilian Higher} Education Institutions External Environment - An Important Factor in Military and Civilian Higher Education Institutions Development

Higher education institutions (hereinafter referred to as HEI), in their capacity as "educational organizations" (Government of Romania, Ministry of Education, 2020) are those that "provide the necessary means for the continuous 
realization of an organizational framework conducive to the development of culture, education and knowledge as basic foundations of society" (Oprean, 2002, pp. 8-9). HEI, as organizations, are perceived as "complex social systems", being "made up of elements that must act concretely to achieve organizational efficiency" (Neagu \& Udrescu, 2008, p. 26). To do this, it must have increased possibilities to integrate organizational variables, members of the organization, the appropriate ability to respond to the action of the external environment. The proper functioning of IIS, viewed as an open system, is based on the management team's knowledge of the factors through which the environment interacts and is interdependent with HEI.

In the case of the MCHEI, the role of the external environment is particularly important, and the influence on the MCHEI can be direct or indirect. As with organizations, detailed knowledge of the external environment of an MCHEI is difficult, if not impossible. This is because "the external environment represents a subjective reality" (Muscalu, Iancu, \& Halmaghi, 2016, p. 135), the components of the external environment being numerous, complex, dynamic, unpredictable and, in some situations, disruptive for the activity within MCHEI.

In the literature for the concept of "external environment of an organization" we do not find a unitary approach because changes that affect the external environment have effects in the medium and long term. In general, the definitions highlight the fact that "the external environment expresses the set of heterogeneous conditions that exert direct or indirect influence on the way the organization operates, constituting the manifestation framework capable of capturing the convergent and divergent evolutions between its components that can favor or to hinder the conduct of its actions" (Cornescu, Mihăilescu, \& Stanciu, 2003, p. 63). Starting from the definitions of the external environment of an organization in the literature, in Table no. 1 we defined the external environment of military higher education institutions (hereinafter referred to as MHEI) and civilian ones (hereinafter referred to as CHEI).

Table no. 1

Definition of the external environment of MHEI and CHEI

\begin{tabular}{|l|l|}
\hline \multicolumn{1}{|c|}{ MHEI } & \multicolumn{1}{c|}{ CHEI } \\
\hline $\begin{array}{l}\text { In our opinion, the external environment of an } \\
\text { MHEI comprises the set of institutions and } \\
\text { other external components that, in the long run, } \\
\text { directly or indirectly influence the achievement } \\
\text { of objectives and its evolution over time. }\end{array}$ & $\begin{array}{l}\text { In our opinion, the external environment of } \\
\text { an CHEI includes all its external elements that, } \\
\text { in the long run, have a direct or indirect } \\
\text { influence on the activity, performance and } \\
\text { obtaining the resources necessary to achieve } \\
\text { the set objectives. }\end{array}$ \\
\hline
\end{tabular}

(Source: Author)

MCHEI and the external environment influence each other: MCHEI influences the environment through its activities, and the external environment influences MCHEI acting within it.

In our opinion, the characteristics of the external environment of the MCHEI are: a) uniqueness - each MCHEI has its external, individualized, unrepeatable environment;

b) dynamism - the external environment of the MCHEI is particularly dynamic due to the changes suffered by the elements that compose it; 
c) adaptability - due to the influences that MCHEI exerts on the external environment, their adaptation to the external environment is active;

d) sensitivity to influence - the entire activity carried out in the MCHEI is determined by the external environment, which, in turn, is influenced by the MCHEI by size, volume of activities, position held among the other MCHEI. This characteristic generates for each MCHEI, the possibility to identify the opportunities and the way to capitalize on them, but also the weaknesses of the external environment and the ways to correct them.

The external environment consists of microenvironment (specific external environment) and macroenvironment (general environment).

In general, the microenvironment of an organization is composed of "external factors with immediate action, which directly influence and affect the organization and over which it has a relative influence and power of control" (Ranf, 2019, p. 24; Dumitrașcu \& Pascu, 2005, p. 20). In our opinion, the microenvironment of an MCHEI is, with small exceptions, identical to the microenvironment of an organization. In Table no. 2 we present what are, in our opinion, the characteristics of the elements of the MHEI and CHEI microenvironment.

Table no. 2

Elements and characteristics of MHEI and CHEI microenvironment elements

\begin{tabular}{|c|c|c|}
\hline \multirow{2}{*}{$\begin{array}{l}\text { The element of the } \\
\text { microenvironment }\end{array}$} & \multicolumn{2}{|c|}{ Characteristics of the elements of a microenvironment: } \\
\hline & MHEI & CHEI \\
\hline \multirow{2}{*}{$\begin{array}{l}\text { Providers } \\
\text { ides the necessary } \\
\text { urces to carry out } \\
\text { ctivity in optimal } \\
\text { conditions }\end{array}$} & $\begin{array}{l}\text { A. which ensures that candidates: } \\
\text { a) military high schools - } \\
\text { most of the candidates come } \\
\text { from this environment; } \\
\text { b) civilian high schools - } \\
\text { some of the graduates of } \\
\text { these high schools want to } \\
\text { pursue a military career; } \\
\text { c) CHEI - a small number of } \\
\text { graduates are pursuing a } \\
\text { military career. }\end{array}$ & $\begin{array}{l}\text { A. which ensures that candidates: } \\
\text { a) civil high schools - most } \\
\text { candidates come from these } \\
\text { high schools; } \\
\text { b) military high schools - a } \\
\text { small number of graduates } \\
\text { are oriented towards civilian } \\
\text { faculties; } \\
\text { c) other CHEI - graduates } \\
\text { who want to have more } \\
\text { specializations; } \\
\text { d) MHEI - graduates who } \\
\text { also follow CHEI; } \\
\text { e) other states of the world. }\end{array}$ \\
\hline & $\begin{array}{l}\text { B. which ensures the smooth } \\
\text { running of the institution's } \\
\text { activities: } \\
\text { a) companies that provide } \\
\text { food for students; } \\
\text { b) utility companies; } \\
\text { c) the economic agents that } \\
\text { provide the fuel; } \\
\text { d) banking institutions. }\end{array}$ & $\begin{array}{l}\text { B. which ensures the smooth } \\
\text { running of the institution's } \\
\text { activities: } \\
\text { a) utility companies; } \\
\text { b) the companies that provide } \\
\text { the raw materials for the } \\
\text { student canteens; } \\
\text { c) banking institutions; } \\
\text { d) companies that provide fuel; } \\
\text { e) economic agents that, in } \\
\text { partnerships, provide students } \\
\text { with the opportunity to do } \\
\text { the internship. }\end{array}$ \\
\hline
\end{tabular}




\begin{tabular}{|c|c|c|}
\hline \multirow{2}{*}{$\begin{array}{l}\text { The element of the } \\
\text { microenvironment }\end{array}$} & \multicolumn{2}{|c|}{ Characteristics of the elements of a microenvironment: } \\
\hline & MHEI & CHEI \\
\hline $\begin{array}{l}\text { Intermediate } \\
\text { role in promoting, } \\
\text { "selling" and } \\
\text { distributing } \\
\text { educational products } \\
\text { to future candidates }\end{array}$ & $\begin{array}{l}\text { Taking into account the specifics } \\
\text { of the military environment and } \\
\text { the "final consumer" is the } \\
\text { Ministry of National Defense } \\
\text { and / or other beneficiaries of } \\
\text { the system of defense, public } \\
\text { order and national security, the } \\
\text { following may be considered } \\
\text { intermediaries: } \\
\text { a) the web page of the } \\
\text { institution; } \\
\text { b) social media (Facebook, } \\
\text { Instagram, etc.) and media; } \\
\text { c) advertising agencies (if the } \\
\text { IISM concludes } \\
\text { advertising contract to } \\
\text { promote the offer of } \\
\text { schooling outside the } \\
\text { military environment). }\end{array}$ & $\begin{array}{l}\text { a) the web page of the } \\
\text { institution; } \\
\text { b) social media (Facebook, } \\
\text { Instagram, etc.) and media; } \\
\text { c) advertising agencies; } \\
\text { d) marketing agencies; } \\
\text { e) human resources recruitment } \\
\text { companies - help graduates } \\
\text { find a job. }\end{array}$ \\
\hline $\begin{array}{l}\text { Customers } \\
\text { the most important } \\
\text { component }\end{array}$ & $\begin{array}{l}\text { Ministry of National Defense } \\
\text { and / or other beneficiaries of } \\
\text { the system of defense, public } \\
\text { order and national security }\end{array}$ & Employers (labor market). \\
\hline $\begin{array}{l}\text { Competitors } \\
\text { HEI that disputes the } \\
\text { same "customers" or } \\
\text { provides the same } \\
\text { educational services }\end{array}$ & $\begin{array}{l}\text { There are no competitors for } \\
\text { MHEI because each military } \\
\text { academy specializes in a } \\
\text { category of forces, and civilian } \\
\text { higher education only trains } \\
\text { future officers whose specialization } \\
\text { is not found in any MHEI. }\end{array}$ & $\begin{array}{l}\text { Other MHEI and / or CHEI in } \\
\text { the country and foreign } \\
\text { countries. }\end{array}$ \\
\hline $\begin{array}{l}\text { Public institutions } \\
\text { institutions with an } \\
\text { impact on achieving } \\
\text { the objectives of the } \\
\text { MCHEI }\end{array}$ & $\begin{array}{l}\text { a) institutions of local and } \\
\text { governmental } \\
\text { administration; } \\
\text { b) banking institutions; } \\
\text { c) the media. }\end{array}$ & $\begin{array}{l}\text { a) institutions of local and } \\
\text { governmental } \\
\text { administration; } \\
\text { b) banking institutions; } \\
\text { c) mass media; } \\
\text { d) citizens' associations - in } \\
\text { exceptional situations. }\end{array}$ \\
\hline
\end{tabular}

(Source: Author)

In conclusion, in the case of MCHEI, certain specific characteristics appear, which are due to certain constraints of the military environment:

a) a civilian candidate must meet certain recruitment conditions, general and specific (age, psychological skills, sports skills, etc.) (General Directorate of Human Resources Management, 2021); limited;

b) the number of places for girls is

c) for each category of forces there is only one MHEI, the places are limited and therefore the competition is higher than in the case of CHEI. 
The macro-environment occupies an important place in the orientation of the IISMC's activity "through the elements of the micro-environment, exerting its influence over a wide and long-term area" (Cornescu, Mihăilescu, \& Stanciu, 2003, p. 67).

MCHEI are dynamic systems that take from the external environment the resources they need in teaching, research or training activities. The results of the use of resources can be observed in the knowledge and skills acquired by the graduates of the respective institutions. This knowledge and skills, through the activities carried out by graduates at work, are transferred to the external environment.

The activities carried out within the MCHEI are influenced by the same categories of factors that influence the activity of any organization: demographic, economic, socio-cultural, management, political, legal, ecological, technical and technological. (Hatch, 2018, pp. 72-75; Nicolescu \& Verboncu, 2008, pp. 65-74; Neagu \& Udrescu, 2008, pp. 26-32.) These effects are short, medium or long term. In Table no. 3 we present how, in our opinion, the categories of factors influence the MCHEI macroenvironment.

Table no. 3

Categories of factors influencing the MCHEI macroenvironment

\begin{tabular}{|c|c|c|}
\hline \multirow{2}{*}{$\begin{array}{l}\text { Categories of factors } \\
\text { influencing the } \\
\text { macroenvironment }\end{array}$} & \multicolumn{2}{|c|}{ How the categories of factors influence } \\
\hline & MHEI & CHEI \\
\hline $\begin{array}{l}\text { Demographic } \\
\text { all the demographic } \\
\text { elements that act on the } \\
\text { MCHEI }\end{array}$ & \multicolumn{2}{|c|}{$\begin{array}{l}\text { a) the competition on the number of places approved for the } \\
\text { admission contest, which will be reflected in the results } \\
\text { obtained by the future graduates; } \\
\text { b) the level of knowledge of the teachers and auxiliary } \\
\text { teaching staff who apply to the competitions for the } \\
\text { teaching and auxiliary teaching positions put up for } \\
\text { competition; } \\
\text { c) the competition for the teaching and auxiliary teaching } \\
\text { positions put up for competition. }\end{array}$} \\
\hline & \multicolumn{2}{|c|}{ a) the revenues allocated from the state budget; } \\
\hline $\begin{array}{l}\text { all the economic elements in } \\
\text { the environment that have a } \\
\text { direct action on the MCHEI }\end{array}$ & $\begin{array}{l}\text { b) practical / field activities } \\
\text { carried out during a } \\
\text { university year; } \\
\text { c) competition for places } \\
\text { available for a fee for } \\
\text { master's, doctoral and } \\
\text { postgraduate university } \\
\text { studies. }\end{array}$ & $\begin{array}{l}\text { b) the number of students } \\
\text { admitted on fee-paying places; } \\
\text { c) increased influence on the } \\
\text { labor market / number of } \\
\text { jobs available for graduates; } \\
\text { d) occupying paid positions } \\
\text { in undergraduate, master's } \\
\text { and doctoral programs, as } \\
\text { well as in postgraduate } \\
\text { programs. }\end{array}$ \\
\hline $\begin{array}{l}\text { Social and cultural } \\
\text { they include the value system, } \\
\text { traditions, coexistence norms, } \\
\text { behavioral habits and }\end{array}$ & \multicolumn{2}{|c|}{$\begin{array}{l}\text { a) influences both through the conscious activity of the } \\
\text { university community and through the groups that are } \\
\text { formed; } \\
\text { b) members coming from other geographical areas, must } \\
\text { adapt to the specifics of the area in which it is located; }\end{array}$} \\
\hline $\begin{array}{c}\text { specific to a geographical } \\
\text { area. }\end{array}$ & $\begin{array}{l}\text { c) the particularities of the } \\
\text { military environment. }\end{array}$ & \\
\hline
\end{tabular}




\begin{tabular}{|c|c|c|}
\hline \multirow{2}{*}{$\begin{array}{l}\text { Categories of factors } \\
\text { influencing the } \\
\text { macroenvironment }\end{array}$} & \multicolumn{2}{|c|}{ How the categories of factors influence } \\
\hline & MHEI & CHEI \\
\hline $\begin{array}{l}\text { Management } \\
\text { planning, organizing, } \\
\text { coordinating and evaluating } \\
\text { the activities carried out }\end{array}$ & $\begin{array}{l}\text { Activities are influenced by } \\
\text { hierarchical relationships and } \\
\text { military regulations. }\end{array}$ & $\begin{array}{l}\text { The activities are influenced } \\
\text { by the management practiced } \\
\text { by the members of the } \\
\text { management team. }\end{array}$ \\
\hline $\begin{array}{l}\text { Policy } \\
\text { stimulating or restrictive } \\
\text { factor for MCHEI activity }\end{array}$ & \multicolumn{2}{|c|}{$\begin{array}{l}\text { Teaching and research activities are influenced by: } \\
\text { a) the internal political climate; } \\
\text { b) the general policy of the Government; } \\
\text { c) policies / strategies / regulations / laws in the educational } \\
\text { field. }\end{array}$} \\
\hline $\begin{array}{l}\text { Legally } \\
\text { the legislative institutional } \\
\text { system establishes the legal } \\
\text { framework for carrying out } \\
\text { the MCHEI activity }\end{array}$ & $\begin{array}{l}\text { The activity is carried out in } \\
\text { accordance with the national } \\
\text { legislation on university } \\
\text { education and the one } \\
\text { specific to the Ministry of } \\
\text { National Defense. }\end{array}$ & $\begin{array}{l}\text { The activity is carried out in } \\
\text { accordance with the national } \\
\text { legislation on university } \\
\text { education. }\end{array}$ \\
\hline $\begin{array}{l}\text { Ecological } \\
\text { they have a major influence } \\
\text { in the activity of the HEI } \\
\text { through the dependence on } \\
\text { natural resources, as well as } \\
\text { through the restrictions } \\
\text { imposed by the legislation } \\
\text { and the actions of } \\
\text { environmental protection. }\end{array}$ & $\begin{array}{l}\text { a) practical activities carried } \\
\text { out in the field; } \\
\text { b) technical solutions are } \\
\text { sought to limit the effects } \\
\text { that practical meetings in } \\
\text { the field have on the } \\
\text { environment. }\end{array}$ & $\begin{array}{l}\text { a) some practical and } \\
\text { production applications in } \\
\text { their own microfactories. }\end{array}$ \\
\hline $\begin{array}{l}\text { Techniques and } \\
\text { technologies } \\
\text { represented by the } \\
\text { endowment of the } \\
\text { laboratories, the level and }\end{array}$ & \multicolumn{2}{|c|}{$\begin{array}{l}\text { a) some of the technical and technological factors can be } \\
\text { assimilated to the existing material base; } \\
\text { b) IISMC have research centers, are involved in } \\
\text { technological development projects and interdisciplinary } \\
\text { research and development, and significant research results } \\
\text { are patented; }\end{array}$} \\
\hline $\begin{array}{l}\text { patents purchased, the } \\
\text { documentation capacity, the } \\
\text { innovation capacity, the } \\
\text { creative capacity, the quality } \\
\text { of the technical-scientific } \\
\text { research. }\end{array}$ & $\begin{array}{l}\text { c) research in collaboration } \\
\text { with other structures from } \\
\text { the Ministry of National } \\
\text { Defense and / or } \\
\text { beneficiaries. }\end{array}$ & $\begin{array}{l}\text { c) research in collaboration } \\
\text { with companies or } \\
\text { enterprises. }\end{array}$ \\
\hline
\end{tabular}

(Source: Author) 
In conclusion, there are also specific MHEI influences in the microenvironment:

a) the places put up for competition for undergraduate studies are budgeted and are filled in full every year, unlike the CHEI where they are budgeted or paid, and there are years when not all of them are filled;

b) managerial activities are influenced by well-established hierarchical relations and military regulations;

c) the activity carried out in MHEI is subject to both the national legislation and the specific legislation of the Ministry of National Defense; d) the training activities carried out in the field have effects on the environment and therefore solutions are sought to reduce the impact of these activities.

\section{Conclusions}

In the case of both the microenvironment and the MHEI macroenvironment, certain specific characteristics appear, which are due to the particularities of the military environment.

MCHEIs become competitive and efficient when the rector together with the members of the management team, in making decisions, take into account the existing interdependence between HEI and its external / environmental environment.

\section{Acknowledgements}

This article is part of the research for the $\mathrm{PhD}$ thesis on the Influence of organizational culture on organizational behavior in the management of sustainable development.

\section{REFERENCES}

Cornescu, V., Mihăilescu, I. \& Stanciu, S. (2003). Managementul organizaţiei. Bucharest: All Beck.

Dumitrașcu, D., \& Pascu, R.V. (2005). Managementul proiectului. Sibiu: Editura Universităţii „Lucian Blaga”.

General Directorate of Human Resources Management. (2021). Intrebări frecvente, available at: https://dmru.mapn.ro/pages/view/104\#r2, accessed on 10 January 2021.

Government of Romania, Ministry of Education. (2020). Organizarea și funcționarea învățământului superior din România, available at: https://www.edu.ro/institutii-invatamantsuperior, accessed on 08 July 2020.

Hatch, M.J. (2018). Organisation Theory. Modern, Simbolic, and Postmodern Perspectives. $4^{\text {th }}$ Edition. Oxford: Oxford University Press.

Muscalu, E., Iancu, D., \& Halmaghi, E.E. (2016). The Influence of the External Environment on Organizations. Journal of Defences Resources Management, Vol. 2, Issue 13, 135.

Neagu, C., \& Udrescu, M. (2008). Managementul organizației. Bucharest: Tritonic.

Nicolescu, O., \& Verboncu, I. (2008). Fundamentele managementului organizaţiei. Bucharest: Universitară.

Oprean, C. (2002). Managementul calității. Sibiu: Editura Universității „Lucian Blaga”.

Ranf, D.E. (2019). Bazele managementului capabilităților organizaţionale. Note de curs. Sibiu: Editura Academiei Forțelor Terestre „Nicolae Bălcescu”. 